\title{
Ammatillisen hoitamisen perusteet
}

ANNU HAHO

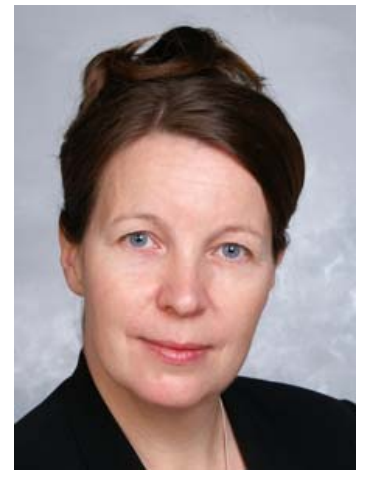

Ammatillinen hoitotyö ei välttämättä sisällä hoitamista, mutta ammatillinen hoitaminen tapahtuu hoitotyössä. Ammatillinen hoitaminen määrittyy käytännöllisenä ja moraalisena taitona, jossa hoitaja hyödyntää eettisiä, tieteellisiä ja teknisiä tietoja. Voidaan puhua hoitamisen eetoksesta. Väitöskirjaansa perustuvassa artikkelissaan kirjoittaja tarkastelee ammatillista hoitamista kolmesta perusedellytyksestä käsin. Ne ovat eksistentiaalinen kriisi, hoitamisen eettiset lähtökohdat sekä tiedon asema ja merkitys.
$\mathrm{T}$ arkastelen tässä artikkelissa länsimaista, hoitotyön modernin aikakauden ammatillista hoitamista. ${ }^{1}$ Kuvaan lähtökohtaisesti hoitamisen ontologiaan, olemisen todellisuuteen, liittyviä kysymyksiä. Hoitamisen ontologinen ${ }^{2}$ tarkastelu edellyttää palaamista perusnäkemysten pariin ja alkuperäisempien kysymysten esittämistä. Niitä ovat esimerkiksi kysymykset, millaiseksi ihminen ja hoitamisen todellisuus käsitetään, mitä on ennen varsinaista ja näkyvää hoitamisen toimintaa sekä mitä hoitaminen on ja mihin se perustuu? Tässä artikkelissa paneudun tarkemmin hoitamisen toimintaa edeltäviin perusteisiin, joita näkee vähemmän esitettävän. Tarkoituksena on osoittaa selkeitä lähtökohtia hoitamiselle. Keskeinen kysymys on, mitkä tekijät vaikuttavat hoitamisen ilmenemiseen ja olemassaoloon?

Filosofisena taustavaikuttajana on Heideggerin (keskeinen teos Oleminen ja aika 2000) olemisen mielen filosofia, joka soveltuu hyvin inhimillisen olemassaolon kysymysten tarkasteluun (katso esim. Kusch 1986, 13). Filosofinen lähtökohta tarkoittaa tässä esiymmärrykseen ${ }^{3}$ perustuvien käsitysten kyseenalaistamista ja uusien esittämistä. Kuvaan ensin hoitamisen käsitettä empiiristen hoitotieteellisten tutkimusten näkökulmasta. Sen jälkeen siirryn pohtimaan ammatillisen hoitamisen perusteita, tekijöitä, jotka perustelevat ammatillisen hoitamisen merkitystä ja olemassaoloa.

Ammatilliseen hoitamiseen vaikuttavia perusteita voidaan nimetä useita. Tähän artikkeliin valitsin tarkastelun kohteiksi eksistentiaalisen kriisin, eettisyyden ja tiedon merkityksen. Ne ovat tekijöitä, jotka kuvaavat hoitamisen olemisen todellisuudessa sitä, mitä voidaan pitää ammatillisen hoitamisen perustavana lähtökohtana (eksistentiaalinen kriisi), mitä voidaan pitää hoitamisen luonnollisena perusolemuksena (eettisyys) sekä sitä, mikä on tiedon asema ja merkitys hoitamisessa (tiedon merkitys).

\section{Hoitamisen käsite}

Hoitamista voidaan kuvata sekä luonnollisena että ammatillisena hoitamisena. Kutsumme luonnolliseksi hoitamiseksi sitä, että ihmiset huolehtivat paitsi itsestään, rakastavat, ruokkivat, kasvattavat, ohjaavat ja neuvovat elämään liittyvissä kysymyksissä myös toisiaan. Lähes kaikissa kulttuureissa ja kautta aikojen siitä ovat olleet vastuussa Nussbaumin $(2000,244)$ käsityksen mukaan naiset. Luonnollinen hoitaminen on toisen ja itsen välittämistä, joka kuvaa tyypillisesti ihmisyhteisön humaania piirrettä (Leino-Kilpi 2004, 19). Se on järkevää ja inhimillistä, Erikssonin (1989) mukaan rakkautta, ”ihmisen, elämän ja ikuisuuden kunni- 
oittamista” (s. 26). Hän toteaa, että hoivaamisen, leikkimisen ja oppimisen kautta ihmiset välittävät toisilleen rakkautta, hoivaa, uskoa ja toivoa (1987, 48; 1989, 26).

Vaikka ammatillisen hoitamisen ydin katsotaan löytyvän luonnollisesta hoitamisesta, liitetään siihen kuitenkin erityisiä piirteitä, joita ei ilmene luonnollisessa hoitamisessa (esim. Eriksson 1987; Leino-Kilpi 2004). Ammatillista hoitamista kuvaavat piirteet professionaalisuus, legaalisuus ja eettisyys. Määrittelen ne hoitotyön kontekstin ominaisuuksiksi, jotka erottavat ammatillisen hoitamisen luonnollisesta ja joita ilman ammatillinen hoitaminen ei ole mahdollista. Professionaalisuus ${ }^{4}$ on ammattimaista toimintaa, jossa korostetaan tieteellisen tiedon merkitystä ${ }^{5}$ ja oikeudenmukaisuuden toteutumista ${ }^{6}$. Lisäksi organisaatio on järjestäytynyt siinä systemaattisesti. Huntin (2004) mukaan hoitotyön professionaalisessa osaamisessa painottuvat tieteellinen ja medisiininen tieto, mutta sen lisäksi siinä korostuvat myös teknologia, työn teknisyys, tehokkuus, poliittisuus, menetelmällisyys sekä terveydenhuollon ideologian ja työpaikkakulttuurin yhtenäistyminen. Legaalisuus viittaa toimintaan, jota säätelevät ja ohjaavat lait, asetukset ja erilaiset ohjeet. Eettisyys on hoitamisen olemassaolon perusehto, joka palautuu ihmisyyteen ja sen merkityskysymyksiin. (Haho 2006.)

Ammatillista hoitamista (professional caring) tapahtuu hoitotyössä. Hoitotyö (health care, nursing care, nursing practice kun painotetaan hoitotyön käytäntöä) on konkreettista hoitoa, hoivaamista ja huolenpitoa (caring). Käsitteenä se otettiin Suomessa käyttöön 1980-luvulla. Sitä ennen puhuttiin sairaanhoidosta (nursing) ja vielä varhaisemmin sairashoitotyöstä. (Voipio 1936; Lauri \& Elomaa 1999; Kalkas \& Sarvimäki 2002.) Hoitotyössä korostuvat hoitajan toiminnallisuus, työn suunnitelmallisuus, tavoitteellisuus ja päämäärien saavuttaminen. Se sisältää elementtejä niin toiminnan yleisestä organisoimisesta kuin käytännön yksittäisistä ratkaisuistakin. Hoitotyön käsite kuvaa laajasti niitä edellytyksiä, kuten ympäristöä ja tietoa, missä hoitaminen on mahdollista. Tutkimukseni (Haho 2006) keskeinen argumentti on kuitenkin se, että hoitotyö ei välttämättä sisällä hoitamista. ${ }^{7}$ Vaikka hoitotyössä ulkonaiset onnistumisen edellytykset olisivat kuinka turvattu, voi asiakas ja potilas silti jäädä vaille hoitamista. Hoitamiseen ei voi ketään pakottaa. Se on eettinen valinta. Hoitaja on viime kädessä henkilökoh- taisesti vastuussa siitä, mitä hoitamisessa tapahtuu.

Tieteellisiin artikkeleihin perustuvassa ammatillisen hoitamisen analyysissä ${ }^{8}$ havaitsin, että hoitamisen käsite ymmärretään sisällöltään monipuolisesti. Artikkeleissa painotettiin selvästi hoitamisen professionaalista ja humaania luonnetta. Tieto- ja taito- osaaminen eivät pelkästään riitä ammatillisessa hoitamisessa, vaan siinä tarvitaan myös sydäntä. Olen antanut sydän käsitteelle merkityksiä, jotka kuvaavat kokonaisvaltaista olemista, läsnäoloa tai hoitamaan asettautumista (esim. Haho 2006 ja 2007b).

Hoitamisen professionaalisuudessa korostetaan ammatillista osaamista kuvaavia ominaisuuksia. Näitä ovat tieteellisesti ja luotettavasti perusteltu tieto, taidot, pätevyys, kyvykkyys, taloudellisuus, vaikuttavuus, asiakkaan ja potilaan tarpeiden huomioiminen sekä oikean auttamismenetelmän valitseminen. Hoitamisen humaania luonnetta kuvaavat puolestaan ihmisen ainutlaatuisuus, kohtaamisen ainutkertaisuus, inhimillisyys, holistisuus ja potilaslähtöisyys. Esimerkiksi eettisessä päätöksenteossa hyväksytään tunteet, tilannesidonnaisuus ja inhimillinen vastuu.

Ammatilliselle hoitamiselle annetaan luonnollisesta hoitamisesta erottavia, tai paremminkin, sitä täydentäviä merkityksiä. Ensinnäkin se on hoitotyötä, jonka pääasiallinen tietoperusta on hoitotieteellisessä tiedossa ja jota toteuttavat terveydenhuoltoalan koulutuksen suorittaneet ammattihenkilöt, kuten sairaan- ja terveydenhoitajat, kätilöt ja lähihoitajat (katso esim. Leino-Kilpi 2004, 19). Toiseksi hoitotyössä hoitajan ja potilaan välinen vuorovaikutus- ja yhteistyösuhde on keskeinen. Sarvimäen (1988) mukaan hoitotyöllä on moraalinen, käytännöllinen ja kommunikatiivinen luonteensa, jonka keskiössä on asiakkaan tai potilaan ja hoitajan luova yhteistoiminta. ÅstedtKurjen (1992) tutkimuksessa asiakkaat ja potilaat kuvasivat hoitotyötä ongelma- ja tehtäväkeskeiseksi tai asiakaskeskeiseksi aina sen orientaatioperustan mukaan, mihin pääpaino hoitotyön käytännössä asettui. Edellisessä asiakkaan ja potilaan ongelma tai sairaanhoitajan tehtävä määrittelee hoitotyön keskeisen sisällön kun taas jälkimmäisessä asiakas itse ja hänen hyvänsä on sairaanhoitajan toimintaa ohjaava tekijä. Sarvimäen ja Åstedt-Kurjen esittämät näkemykset hoitotyön sisällöistä ovat huomion arvoisia vielä tänä päivänäkin.

Ammatillinen hoitaminen määritellään käytän- 
nöllisenä ja moraalisena taitona, jossa hoitaja hyödyntää eettistä, tieteellistä ja teknistä tietoa (Blondeau 2002) sekä kulttuurien tietämystä (Cortis \& Kendrick 2003; Hansen 2004). Konkreettisen tekemisen lisäksi hoitamisella katsotaan olevan myös aatteellinen perusta (Matilainen 1997, 2002; Tuomi 1997; Eriksson et al. 1995, 2003). Eriksson käyttää käsitettä hoitamisen eetos. Se kuvaa hoitamisen eettistä arvopohjaa eli sitä, mistä nimenomaan hoitaminen on tunnistettavissa. Toisin sanoen, mikä hoitamisessa on merkityksellistä, kuvaa oleellisesti sitä. Eriksson on tutkinut hoitamisen ideaa ja alkuperää sekä luonut Pohjoismaissa ensimmäisen hoitoteorian, karitatiivisen hoitoteoria. Hänen esittämänsä teesin mukaan ammatillinen hoitaminen on kärsimyksen lievittämistä, laupeuden työtä. Caritas-motiivi perustuu hänen teoriassaan uskoon, toivoon ja rakkauteen, jotka mahdollistavat ihmisen eheytymisen. (Katso esim. Grönroos et al. 1994, 508; Eriksson 1990, 65, 68, 72; 1995, 35; 1996, 1, 5, 7.)

Edellä mainitut tutkimukset kuvaavat ammatillista hoitamista pääasiassa erityistieteen, hoitotieteen, näkökulmasta sekä sitä, miten se eroaa luonnollisesta hoitamisesta. Katsauksessa ei käy kuitenkaan vielä ilmi, miksi ammatillista hoitotyötä tarvitaan ja mikä on ammatillisen hoitamisen merkitys. Miksi hoitotyötä tehdään? Mitkä tekijät voidaan katsoa vaikuttavan ammatillisen hoitamisen olemassa oloon? Mihin ammatillinen hoitaminen perustuu?

\section{Eksistentiaalinen kriisi hoitamisen läh- tökohtana}

Ammatillisen hoitamisen tarpeen luo aina ihminen. Ihminen kokevana, tuntevana ja kokonaisvaltaisena persoonana hakeutuu tai joutuu turvautumaan ammatti-ihmisten tarjoamaan apuun, kun ei itse selviydy päivittäisistä toiminnoistaan tai hänellä on jokin selviytymistä haittaava sairaus tai vamma. Se, millainen käsitys hoitotyöntekijöillä on ihmisen eksistenssistä, ihmisen olemuksesta ja sen suhteesta elämän muutoksiin, sairastumiseen, onnettomuuksiin, oman tai läheisen kuoleman kohtaamiseen, vaikuttaa koko hoitotyön lähtöasetelmaan. Tarkastelen tätä kysymystä Heideggerin (2000) esittämien käsitteiden, olemisen, kuoleman ja huolen näkökulmista.

Minuuden olemuksen eli subjektikokemuksen ${ }^{9}$ pohtimisella on hoitotyössä merkitystä kahdesta- kin syystä: asiakas tai potilas on minä ja hoitaja on minä. Molemmat ovat tuntevia ja kokevia ihmisiä ja molemmilla on ainutlaatuinen elämänhistoria. Eksistenssin eli ihmisen olemisen ymmärtäminen vaikuttaa siihen (tai johtuu siitä), millainen käsitys hänellä on itsestään ja muista ihmisistä, mitä hän pitää tärkeänä elämässään, mitä hän valitsee, hoitamisen näkökulmasta myös se, mitä hoitaja havaitsee ja mitä hänellä on mahdollisuus havaita.

Tietoisuuden oivaltaminen, oman olemuksensa ymmärtäminen, lähtee omasta itsestä käsin, ei ulkopuolisesta todellisuudesta. Heidegger (2000, esim. 48) määritteli ihmisen olemista täälläolemisen (Dasein) kautta. Täälläolo on paikkka (Da), missä voidaan oleminen paljastaa, ja se tapahtuu faktisessa elämässä eli elämässä itsessään. Heideggerin tarkoittama täälläolo kuvaa ihmisen olemisen muotoa, jossa on yhtä aikaa läsnä sekä menneisyys että tulevaisuus. Kuolema kulkee Heideggerin näkemyksen mukaan koko ajan olemisen mukana, "saatavana” (Heidegger 2000, 48, 298), joka koko ajan täyttyy. Syntyminen ei lakkaa olemasta läsnä ennen kuin ihminen on kuollut, alkua ei voi määritellä ilman loppua, elämää ilman kuolemaa (Heidegger 49, 305, 307), ja lisään vielä, eikä terveyttä ilman sairautta. Ihmisen eksistentiaalisessa olemuksessa nämä ulottuvuudet ovat yhtä aikaa läsnä.

Tästä näkökulmasta ajattelen myös ihmisen sikiövaiheen sellaiseksi elämään kuuluvaksi vaiheeksi, jossa syntyminen ja kuoleminen kuuluvat vielä "saatavien”, "ei-vielä” ja täyttyvien tulevien kokemusten piiriin. Tulkitsen siten, että täälläolo luo siis mahdollisuuden ihmisen olemuksen täyttymiselle sellaiseksi kuin sen on mahdollisuus tulla. Siinä on läsnä historiallisuus, niin menneenä, nykyisyytenä kuin tulevanakin.

Täälläolemisen kokemukseen vaikuttaa elämän rajallisuuden ymmärtäminen. ${ }^{\mathbf{1 0}}$ Heideggerin näkemyksen mukaan kuoleman hetkellä ihmisen olemisen kokemus on täydellisimmillään. Hän kohtaa silloin aidosti kuolevaisuutensa, olevaisuutensa ja täälläolonsa rajallisuuden. (Heidegger 2000, 47, 48, 72, 74.) Onko näin, että vasta kuolinhetkellämme ymmärrämme, mitä ihmisyys ja ihmisenä oleminen lopulta on? Ihminen ei voi kokea mitään varmaa ja todellista kuin tapahtumia syntymän ja kuoleman välissä. Historiallisuus ja traditioon kuuluminen mahdollistaa ymmärtämisen. Rajallisuuden oivaltaminen on tiedostamista, joka lähtee omasta itsestä käsin, ei ulkopuolisen maailman todellisuudesta. Hoitamisessa kohtaavat 
siis kaksi minää, hoitajan minä ja asiakkaan tai potilaan minä. Rajallisuuden ja olemassa olemisen oivaltamisen kokemuksia nämä minät voivat jakaa kanssakäymisessään. Hoitaminen perustuu paljolti vuorovaikutukselliseen kanssakäymiseen, jossa sekä hoitaja että asiakas tai potilas antavaa merkityksiä olemiselleen.

Huoli liittyy Heideggerin mukaan ihmisen perusominaisuuteen, joka "hallitsee ihmisen ajallista kulkua maailmassa” (2000, 42, 249). Sillä ei tarkoiteta tässä yhteydessä yleisesti ymmärtämäämme käsitystä murheesta tai levottomuudesta. Huoli ilmentää maailmassa olemisen tapaa. Se on myös täälläolon eksistentiaalisen tulkitsemisen, olemisen perusmuoto. Sen kautta ihmisellä on siis maailmaan reaalinen yhteys. Se näkyy ihmisen toiminnassa siten, mihin hän "antautuu" tai "heittäytyy", toisin sanoen, mitä hän pitää elämässään merkityksellisenä ja tärkeänä.

Huoli Heideggerin antamassa merkityksessä näkyy hoitotyössä erityisesti päätöksentekotilanteissa. Mitä hoitaja havaitsee? Mitä hän asettaa vaihtoehdoiksi? Mitä hän valitsee ja lopulta miten hän hoitaa? Huolen ansiosta hoitaja kykenee kiinnittymään siihen hetkeen ja tilanteeseen, missä hän kohtaa asiakkaan ja potilaan, hän ei toimi siis pelkästään itsetietoisuuden varassa. Reaalinen maailma, toinen minä elämänhistorioineen tässä ja nyt erityisessä tilanteessa, on autenttisesti läsnä, vieläpä olemisen ja toiminnan syynä ja lähtökohtana. Huolen ohjaamana hoitaja jäsentää tilanteessa olevia merkityksiä, arvottaa niitä oman ja hoitamisen merkitysmaailman mukaisesti, valitsee ja toimii. Huoli ilmenee tiedostamisena, tulkitsemisena ja ymmärtämisenä.

Huoli ilmaisee myös sitä, mitä hoitotyössä yleisesti pidetään tärkeänä ja merkityksellisenä. Valinta ei ole pelkästään henkilökohtainen vaan myös ammatillinen. Ammattikunta on siten kokonaisuudessaan vastuussa siitä, mitä asioita hoitamisessa pidetään tärkeinä ja mitkä nostetaan toimintamalleiksi. Arvoperustoja tulee pohtia yhdessä ja julkisesti. Esimerkiksi yhteiskunnassamme esiintyviä hoitotyön ongelmia, kuten vanhushoitotyön tilaa, on hyvä tuoda julkiseen dialogiin. Mistä tekijöistä muodostuu hoitotyössä yhteinen ”työnäky”? Onko hoitotyön akateemisilla johtajilla ja yksittäisillä työntekijöillä taitoa luoda hoitotyöstä inhimillistä, asiakkaan ja potilaan eksistenssin perusteista nousevaa ja hyvää tavoittelevaa sekä pätevää hoitamista, jossa inhimillisyys on ammatillisuuden perusehto? (kat- so myös Haho 2007b.)

Eksistentiaalinen kriisi tarkoittaa muutosta. Sairastuminen, onnettomuus, vammautuminen tai kuoleminen johtaa siihen, että ihmisen olemiseen ja olemukseen liittyy jokin uusi oivaltava kokemus. Aikaisemmin koettu, tuttu ja tavallinen muuttaa muotoaan uudeksi, oudoksi, epätavalliseksi ja jopa pelottavaksi. Merkittävää kuitenkin on, että ihminen voi antaa muutokselle positiivisia ja negatiivisia merkityksiä. Lisäksi se tarkoittaa aina myös mahdollisuutta.

Ajattelemme usein hoitotyössä jonkin tietyn olomuodon olevan tavoiteltavampi kuin toinen. Terveyttä pidetään tavoiteltavana arvona ja sairautta vältettävänä pahana sekä elämää kuolemaa toivottavampana. Silti olemme kuulleet asiakkaiden ja potilaiden kokemuksista, että sairaus tai onnettomuus on voinut koitua arvokkaaksi kokemukseksi elämän kokonaisuutta ajatellen. Kuolema on voinut jossakin ihmisen elämän tilanteessa tuntua toivottavammalta kuin elämän jatkuminen. Heideggerin olemisen mielen filosofian näkökulmasta tämä on ymmärrettävää ja vaikuttaa luonnolliselta. Nimittäin hän ei filosofiassaan arvota olemisen muotoja, vaan pyrkii minuuden ymmärtämiseen ilman eettisiä tai moraalisia kannanottoja.

\section{Eettisyys hoitamisen lähtökohtana}

Esitän väitöskirjassani argumentin, jonka mukaan hoitaminen on mahdotonta ilman sen eettistä olemusta. Eettisyys risteää jokaista hoitamista kuvaavan väittämän olemusta, moraalisuutta, autonomisuutta ja universaaliutta. Hoitaminen on siis sinänsä eettistä. Mikäli näin ei ole, ei voida puhua hoitamisesta. Kyseessä voi siinä tapauksessa olla esimerkiksi hoitamattomuus, välinpitämättömyys, huolimattomuus, kieltäytyminen, syrjiminen, heitteillejättö, vahingon tai jopa kuoleman tuottaminen. Se voi tarkoittaa myös pelkkää teknistä tehtävien ja velvollisuuksien suorittamista. Hoitaminen sisältää aina ja välttämättä toisen ihmisen eli asiakkaan tai potilaan hyvän tavoittelemisen ja sen toteuttamisen. Hoitaminen tuo hoitotyöhön inhimillisyyttä ja arvokkuutta sekä tuottaa hyvää. Tarkastelen tässä eettisyyttä inhimillisen hoitamisen taidon sekä rakkauden ja ihmisen olemuksen huomioimisen näkökulmista.

Hoitaja joutuu työssään kohtaamaan ihmisen inhimilliseen elämään liittyviä asioita eli kohtaamaan ihmisiä erilaisissa eksistentiaalisen kriisin 
tilanteissa. Tilanteet voivat olla tunnepitoisia: iloisia tai surullisia sekä toivoa, epätoivoa, helpotusta tai kauhua sisältäviä. Hoitaja joutuu toimimaan myös asiakkaan tai potilaan peruselintoiminnoista huolehtivien laitteiden ja koneiden kanssa, puuttumaan intimiteettiin ja tekemään päätöksiä tämän puolesta. Asiakas tai potilas on riippuvainen hoitajan välittömästä tahdosta ja toiminnasta. Hän vaikuttaa asiakkaan ja tämän läheistensä henkisiin, sosiaalisiin ja fyysisiin elämän edellytyksiin ja mahdollisuuksiin. Näissä tilanteissa hoitajan tiedot, taidot ja arvomaailma ovat asiakkaiden ja heidän omaistensa, sosiaali- ja terveysalan organisaation ja kollegoiden välittömän tarkkailun alaisena. (Esim. Benjamin \& Curtis 1992; Bandman \& Bandman 1995; Sarvimäki 1988; Kalkas 2002; Leino-Kilpi 2004) Täten ei ole yhdentekevää, millainen näkemys hoitajalla on hoitamisesta.

Inhimillinen hoitamisen taito on tavoitteellista eli tähtää hyvään ja kuvaa ihmiselle ominaista moraalista taitoa. Luonnollisena ihmisyyteen kuuluvana ominaisuutena sen merkitystä ei ole kyseenalaistettu, mutta juuri sen vuoksi se on usein sivuutettu ${ }^{11}$.

Tunteet ovat moraalisten taitojen lähtökohtina. Usein tunteiden merkitystä käyttäytymisessä ja päätöksenteossa vähätellään tai niiden ilmaisemista pidetään epäsopivana. Inhimillisessä kanssakäymisessä ne ovat kuitenkin keskeisessä asemassa. Ne eivät ole mielivaltaisia, vaan perustuvat harkintaa, ymmärrykseen, tulkintaan ja arviointiin sekä sisältävät erityisiä arvoja ja erityistä tietoa. (Nussbaum 2000, 265; Nussbaum 2001, 116.) Tunteet eivät ole pelkästään impulsiivisesti syntyviä hajanaisia toimintoja, vaan tavoitteellisia, arvokkaita ja järkeviäkin, koska ovat sinänsä hyviä ja tavoittelevat ihmiskunnan eheyttä ja säilymistä (Nussbaum 2002, 265).

Nussbaum (2000; 2001; 2002) liittää moraalisen taidon feminiinisyyteen. Tämä taito tulee esiin erityisesti toisen ihmisen hoitamisessa. Hän mainitsee, että rakkaus, karitatiivisyys, ymmärtämisen taito, sosiaalisuus, toisen ihmisen huomioiminen ja toivon ylläpitäminen ovat feminiinisiä taitoja, joille ei ole poliittisessa käsitteistössä tilaa.

Inhimillinen hoitaminen perustuu universaaleihin humaanisiin arvoihin, joista Watson $(1979,10)$ mainitsee ystävällisyyden, välittämisen sekä itsensä ja toisten rakastamisen. Yleensä elämään kuten hoitamiseenkin liittyy paljon kysymyksiä, joihin ei voida vastata jollakin periaatteella tai säännöllä. Tieto perustuu ihmisten yhteisölliseen humanismin kokemukseen. Hoitaja voi joutua joskus tilanteeseen, missä hän tunnistaa ihmisyyden rajan ylittyneen. Mikään laki tai eettinen ohje ei ohjaa häntä niiden tunnistamisessa, vaan ymmärtäminen tapahtuu intuitiivisesti. (Katso myös Hunt 2004.)

Inhimillinen hoitamisen taito vaikuttaa asiakkaan tai potilaan kokemaan arvokkuuteen ja hyvään hoitoon. Se vaikuttaa jopa tervehtymiseen ja kuntoutumiseen. Ihmisen olemusta kuvaavia moraalisia taitoja ovat tunteiden ilmaiseminen, niiden salliminen ja ymmärtäminen, hoivaaminen, toisen huomioiminen, toivon ylläpitäminen, ihmisyyden rajojen tunnistaminen, rakkaus ja sosiaalisuus. Asiakkaalla tai potilaalla tulee oikeuksien ja velvollisuuksien lisäksi olla mahdollisuus myös ihmisenä olemiseen sellaisenaan, tapoineen, toiveineen ja elämänkatsomuksineen. Tämä tarkoittaa sitä, että hoitaja kohtaa hänet ihmisenä, ei velvollisuuksien tai lakiin perustuvien vaatimusten kohteena.

Rakkautta hoitamisen lähtökohtana voidaan tarkastella antiikin kreikan philos käsitteen avulla, mikä tarkoittaa rakkautta viisauteen ja hyvään. Sen avulla voidaan ymmärtää ja kunnioittaa elämää ja maailmaa nimenomaan sen itsensä tähden. Huomio kiinnittyy itsestä toiseen ja sitä kautta toisen ihmisen hyvän saavuttamiseen. Rakkaus tuo arvokkuutta hoitamiseen. (Esim. Tarlier 2000, 1067; Kalkas \& Sarvimäki 2002, 28; Matilainen 2002, 79; Paldanius 2002, passim..)

Joidenkin tutkimusten mukaan (esim. Eriksson 1995; Matilainen 2002; Paldanius 2002; Myllylä 2004) hoitotyö perustuu lähimmäisenrakkauteen, mikä on lähtöisin kristillisen etiikan ajattelutavasta ja joka nimetään agapeeksi. Siinä lähtökohtana on Jumalan rakkaus ihmiseen, mikä mahdollistaa ihmisten välisen lähimmäisenrakkauden. On kuitenkin otettava huomioon, että nämä tutkimukset edustavat länsimaista kulttuuria ja kristillistä etiikkaa, kun taas näkemykseni mukaan hoitaminen on universaali ilmiö, jonka konteksti on maailmankatsomuksista riippumaton. Kristilliseettinen lähimmäisenrakkaus tarjoaa kuitenkin merkittävän näkökulman ja mahdollisuuden hoitoeettisten kysymysten tarkastelulle.

Fitzerald \& Hooftin (2000, 485, 487, 489) tutkimuksen perusteella rakkauteen perustuva hoitajien toiminta toi hoitamiseen jotakin enemmän, kuin mitä heidän ammatillinen velvollisuutensa heiltä edellytti. Heidän ajattelunsa oli monipuolista ja 
toimintatapansa joustavaa. He kykenivät ottamaan toisen ihmisen hyvään johtavia kompetenttejä riskejä, mikä tarkoitti totuttujen tapojen ja ammatillisiin uskomuksiin perustuvien tietojen tunnistamista ja syrjäyttämistä. Rakkaus edellytti tämän tutkimuksen perusteella hoitajalta tahtoa, sitoutumista sekä toisen edun ja hyvän asettamista oman edun edelle.

Rakkaus ja empatia auttavat hoitajaa myös tunnistamaan hoitamisen tilanteessa eteen tulevia moraalisia kysymyksiä (Reynold et.al. 2000). Samaa tarkoittaa Watsonkin $(1979,28)$ toteamalla, että empaattisuus on taitoa ja kykyä kokea sekä ymmärtää toisen ihmisen tunteita ja hänen niille antamia merkityksiä. Vapaassa hoitamisen ilmapiirissä myönteiset tunneilmaisut ovat sallittuja siinä missä kielteisetkin.

Kokonaisuudessaan edellä esitettyjä tutkimustuloksia voi tulkita siten, että rakkaus edellyttää toisen ihmisen asemaan asettautumista, mikä on myös tunnusomaista empatiassa. Lisäksi rakkautta kuvaavina piirteinä voidaan pitää ihmisen itsenäisyyttä, henkilökohtaista sitoutumista hoitamiseen, rohkeutta ja avoimuutta.

Moraalilausumien esittäminen yksityiskohtaisesti, kuten mikä on hyvää ja mikä vältettävää hoitamisessa, ei ole ongelmatonta ja edellyttää harkintaa sekä tilanteen ja moraalifilosofisten perustelujen tuntemista.

\section{Tiedon merkitys hoitamisessa}

Tutkimukseni (Haho 2006) fenomenologishermeneuttinen näkökulma haastoi minut pohtimaan tiedon merkitystä. Tieto, tiedostaminen ja ymmärtäminen ovat hoitamisessa keskeisessä asemassa ja esillä näkymättömästi. Nimittäin ymmärtäminen ${ }^{15}$ on ilmiöille annettujen yhteisten merkitysten oivaltamista, tietoisuus tarkoittaa ilmiöiden tulkitsemisen mahdollisuutta ja tieto on "kokemuksessa itsessään aukeavaa konkreettista mieltä” (Kupiainen 2005, 89). Tulkintani mukaan hoitotyössä ja hoitamisessa esiintyvien ilmiöiden ja niiden olemusten tiedostaminen, ymmärtäminen ja ilmaiseminen ovat mahdollisia avoimen asettautumisen, kokemuksellisuuden, tulkitsemisen ja dialogin kautta. Niiden välityksellä hoitaja kykenee havaitsemaan, tekemään päätöksiä, valitsemaan, vaikuttamaan, toimimaan, ilmaisemaan itseään ja jakamaan kokemuksiaan. Tieto vaikuttaa lopulta siihen, millä tavoin eettisyys toteutuu käytännön työssä.

Hoitotyön tietoperustaa määritellään monin eri tavoin. Esimerkiksi Carper (1978) jakaa tiedon lajit empiiriseen, eettiseen, persoonalliseen ja esteettiseen tietoon. Tässä artikkelissa en keskity niinkään tiedon lajien määrittelemiseen tai analyysiin, vaan siihen, mikä merkitys tiedolla (lisäksi millaisella tiedolla), tiedostamisella ja ymmärtämisellä on hoitamisessa. Käsittelen hoitamisen tiedon erityistä, yksityistä ja praktista ominaisuutta niille annettuine merkityksineen. Tieto on vaikuttanut ja vaikuttaa edelleen ammatilliseen osaamisen laatuun ja identiteetin muodostumiseen. Se on kehittymisen ehto.

Hoitamisen tieto on luonteeltaan erityistä ja yksityistä. Jokainen hoitamisen tapahtuma ja vuorovaikutustilanne on ainutlaatuinen ja toistamaton. Olipa hoitotoimenpide, esimerkiksi katetroiminen tai haavahoito, siinä mukana oleville ihmisille miten tuttua tahansa, on se hoitotapahtumana silti ainutlaatuinen. Molemmat, niin asiakas tai potilas kuin hoitajakin, tuovat siihen mukanaan oman henkilöhistoriansa, kokemusmaailmansa ja niille antamat merkityksensä. Tiedon erityinen ja yksityinen luonne merkitsee tässä nimenomaan tilanteen ainutlaatuisuutta ja toistamattomuutta sekä sitä, että ihmiset kokevat hoitamisen tapahtuman yksilöllisesti ja antavat sille erilaisia merkityksiä.

Hoitamisen tiedon erityiseen ja yksityiseen luonteeseen vaikuttavat sille annetut moraaliset ja eettiset merkitykset. Asiakkaan tai potilaan ja hoitajan vuorovaikutussuhde on olemukseltaan ainutlaatuinen ja herkkä (esim. Watson 1988; Sarvimäki 1988; Tarlier 2004), joka edellyttää hoitajalta täydellistä läsnäoloa (esim. Easter 2000). Sen olennaisia piirteitä ovat toisen kunnioittaminen, keskinäinen luottamus ja vuorovaikutuksen molemminpuolisuus. Hoitamisessa korostuvat osallistuminen, harmoninen vuorovaikutussuhde, tarvelähtöisyys, tilannekohtaisuus ja kokonaisvaltaisuus. Toisin sanoen asiakasta tai potilasta hoidetaan hänen tilanteestaan, tarpeistaan ja persoonastaa käsin, yksilökohtaisesti. (Botes 2000, 1071, 1072.)

Läsnäolo luo inhimillisesti turvallisen ja avoimen ilmapiirin. Huolenpito asiakkaasta tai potilaasta on kokonaisvaltaista, virittää toivoa selviytymisestä ja jaksamisesta, tukee peruselintoimintojen ja tarpeiden toteutumista sekä on luonteeltaan ystävällistä, rauhallista ja inhimillisesti arvokasta. Hoitaja, joka on läsnä hoitamisen tapahtumassa, kykenee hahmottamaan, ymmärtämään ja jäsentämään hoitamisen tilanteessa esiintyviä 
ilmiöitä ja tekijöitä. Heideggerin huolen ja hoitotieteellisen läsnäolon käsitteistä löytyy keskinäinen yhteys. Läsnäolo, huoli, mahdollistaa reaalisen yhteyden hoitamisen kontekstiin. Kivun aistiminen, toiveiden, odotusten ja tunteiden huomioiminen, esimerkiksi kaipaus, suru, ilo epätoivo ja helpotus, viestitään vuorovaikutustilanteissa ilmeiden, asentojen, eleiden ja koko ihmisen olemuksen välityksellä. Niiden tunnistaminen edellyttää hoitajalta herkkyyttä ja huomioimisen taitoa sekä kiireetöntä, avointa ja rauhallista läsnäolemista.

Ihmisen olemukseen liittyvä hiljainen tieto, Parviainen (2000) määrittelee sen keholliseksi tiedoksi, on asiantuntijuutta, jota tarvitaan eri ammateissa, myös hoitotyössä (160). Hänen määritelmänsä mukaan kehollinen tieto on mykkää ja kohdistunutta, joka edellyttää kehollista taitoa ${ }^{16}$, eikä sitä ilmaista sanojen tai lauseiden muodossa. Sen sijaan kehollisen tiedon voi aistia ja havaita. Tietolähteenä se on merkityksellinen ja relevantti.

Hoitamisen tiedon perusteiden monipuolisuudesta kertoo Nurmisen (2000) tutkimus hoitamiseen liittyvästä hiljaisesta ja intuitiivisesta tiedosta. Hiljainen tieto on sisäistä tunnetta, intuitiota, siitä, miten pitää toimia ja mitkä ratkaisut johtavat hyvään ja oikeaan. Etiikan teoriassa intuitionismi tarkoittaa moraalifilosofista suuntausta, jonka mukaan teon hyvyyttä ei ole mahdollista päätellä sen havaittavien ominaisuuksien mukaan. Hyvyys oivalletaan välittömästi, intuition avulla. (Pietarinen \& Poutanen 2000, 15, 29.)

Sisäinen tunne voi syntyä kokemuksen kautta. Ammatissaan pitkään toimineella hoitajalla on kokemuksellista tietoa ihmisten erilaisista elämäntilanteista sekä terveyden ja sairauden tiloista. Lisäksi hän saattaa oivaltaa yhtäaikaisesti eri asioita, ymmärtää ja käsittää niiden keskinäisiä yhteyksiä. Nurmisen (2000) tutkimuksessa intuitiivisuus lähti hoitajista itsestään, kun he pohtivat ajattelunsa ja toimintansa perustoja. Empiirisessä ja henkilökohtaisessa tiedossa yhdistyivät kaiken kaikkiaan luovuus, persoonalliset ominaisuudet, kokemus ja teoriatieto. Lopulta se johti merkitykselliseen tietoon, joka mahdollisti eläytymisen toisen tilanteeseen.

Hoitamisen tieto on praktista. Praktisuudella viittaan tässä käytännölliseen tietoon, joka kohdistuu hoitamisen taitoihin ja ympäristöön. Sillä on myös eettinen ulottuvuutensa. Onhan hoitamisen eettinen tieto käytännöllistä siinä merkityksessä, että se tuottaa hyvää ja johtaa oikeisiin ratkaisuihin (esim. Blondeau 2002, 252). Toisin sanoen hoitamisen eettinen ja praktinen tieto on funktionaalista, jolla on selkeä tehtävä ja tavoite. Universaali objektiivinen tieto toimii myös hyvän ja oikean toiminnan perustana. Tämän hyväksyminen johtaa ristiriitaan, jota en käsittele tässä yhteydessä. Nimittäin voiko hoitamisen tieto olla samanaikaisesti erityistä ja yksityistä sekä yleistä eli universaalia?

Hoitotieteellisessä keskustelussa (esim. Fitzgerald \& Hooft 2000; Blondeau 2002; Whelton 2002) on pohdittu sitä, perustuuko hoitamisen tieto pikemminkin taiteellisiin (fine art) kuin käytännöllisiin (practical art) taitoihin. Blondeaun (2002) käsityksen mukaan se on enemmän käytännön taitoa kuin taiteellisuutta vaativaa ja kauneuden käsitykseen liittyvää taitoa ja se todellistuu hoitajan toiminnassa. Silti hän näkee siinä myös esteettisen ulottuvuuden, jonka eettisyys, toiminnan hyvä, siihen nimenomaan tuo. Hän pitää hoitamisen käytännöllistä taitoa moraalisena taitona, joka on alisteinen hoitoetiikalle.

Tutkimuksessani esittämäni argumentti, hoitaminen on sinänsä eettistä, on Blondeaun näkemyksen kanssa samansuuntainen. Hoitaminen on sinänsä hyvää ja tuottaa hyvää. Hyvällä on tietty funktio, sille voidaan antaa naturalistisia ominaisuuksia, jotka palautuvat asiakkaan tai potilaan hyvään. Sen sijaan hoitotyö ei välttämättä sisällä hoitamista, vaikka hoitaja toimisi kuinka teknisesti taitavasti tai juridisesti oikein. (Haho 2006; 2007 a jab.)

Käytännöllinen tieto kohdistuu auttamismenetelmiin ja universaaliin objektiiviseen tietoon, johon katsotaan kuuluvan esimerkiksi luonnontieteen lait ja ihmisen käyttäytymisen psykologia. Lisäksi tieto ympäristöstä ja asiakkaan tai potilaan olosuhteista on käytännöllistä, koska se vaikuttaa välittömästi hoitajan toimintaan. Cortis \& Kendrickin (2003) tutkimuksen mukaan hoitajan erilaisten kulttuurien tietämys sekä ymmärtävä suhtautuminen erilaisista ympäristöistä tulevia asiakkaita tai potilaita kohtaan helpottaa yhteisten tavoitteiden laatimista, toiminnan suunnittelemista ja niiden toteuttamista sekä vähentää keskinäisiä ristiriitoja. Potilaat toivoivat, että hoitajat ottaisivat heidät paremmin huomioon, kuuntelisivat heitä, kommunikoisivat heidän kanssaan sekä osoittaisivat empatiaa.

Myös Rosqvistin (2003) tutkimus osoitti, että hoitajan suhtautuminen potilaaseen ja käyttäytyminen potilaalle kuuluvassa henkilökohtaisessa tilassa, jota ovat esimerkiksi keho, sänky tai 
potilashuone, kuvaa hoitajan taitoa ymmärtää ja soveltaa eettistä tietoa käytännön tilanteessa. Ympäristön huomioiminen lisää asiakkaan tai potilaan itsemääräämisen ja arvokkuuden tunnetta. Noreksen (1993) tutkimus vanhusten olemassaoloon vaikuttavista tekijöistä vahvistaa tämän.

Ympäristö vaikuttaa siten myös siihen, millaisia merkityksiä hoitamiselle annetaan, kuinka nämä merkitykset tiedostetaan ja lopulta siihen, millaista tietoa pidetään merkityksellisenä ja millaisia toimintatapoja valitaan. Nämä tulevat esiin muun muassa eräissä Oulun yliopistossa valmistuneissa hoitotieteellisissä väitöskirjoissa, joissa tutkittiin mielenterveysasiakkaiden häpeän tunteen käsittelemisen tapaa (Vuokila-Oikkonen 2002), vanhusten selviytymisen ja kuntoutumisen kokemuksia (Purola 2000), mielenterveysasiakkaiden hyvän hoidon kokemuksia (Kokko 2004) sekä hoitajien keskuudessa ilmenevää kateutta (Heikkinen 2003).

Käytännölliset taidot, järki ja harkitsevuus hoitamisessa hyödyntävät asiakasta tai potilasta tuottamalla hänen elämäänsä ja terveydentilaansa hyviä asioita. Ne helpottavat vointia, lisäävät terveyttä, poistavat tuskaisuutta tai kipuja, tarjoavat selviytymisen taitoja, antavat toivoa ja vaikuttavat rohkaisevasti jaksamiseen sekä mahdollistavat inhimillisen kuolemisen.

\section{Loppusanat}

Olen tarkastellut tässä artikkelissa ammatillista hoitamista sen perusteiden, en niinkään yleisesti esitettävien näkyvien tulosten, näkökulmasta. Sen olemisen todellisuutta kuvaaviksi keskeisiksi piirteiksi rajasin tässä eksistentiaalisen kriisin, hoitamisen eettisyyden ja tiedon merkityksen. Ammatillisen hoitamisen perusteiden kysyminen tarkoittaa palaamista hoitamisen ontologisiin lähtökohtiin; mitä on ennen varsinaista näkyvää hoitamisen toimintaa, mitkä tekijät käynnistävät hoitamisen ja mitkä erityiset piirteet kuvaavat sitä. Voimme vaikuttaa varsinaiseen toimintaan, jos havaitsemme ja tiedostamme toimintamme peruslähtökohdat, kykenemme määrittelemään siihen liittyviä osatekijöitä ja ymmärrämme vielä niiden erilaiset merkitystaustat. Ammatillisen hoitamisen perusteiden tiedostaminen auttaa myös ongelmatilanteissa ristiriitojen ratkaisemisessa, toiminnan uudelleen arvioimisessa ja sen kehittämisessä.

Artikkelini tehtävänä on ollut kiinnittää huomio ammatillisen hoitamisen perusedellytyksiin, eksistentiaaliseen kriisiin, hoitamisen eettisiin lähtökohtiin sekä tiedon asemaan ja merkitykseen. Eksistentiaalinen kriisi on asiakkaan tai potilaan elämässään kokema muutos, jonka vuoksi hän on lähtenyt hakemaan ammatillista apua. Avun tarve voi johtua sairastumisesta, synnyttämisestä, kuolemisesta tai vammautumisesta sekä kivun, toivottomuuden tai tuskaisuuden kokemuksesta. Hoitamisen tapahtuman käynnistäjänä on asiakas tai potilas, tuntevana ja kokevana ihmisenä, jolla on oma elämän historiansa ja näkemyksensä sekä eksistentiaaliseen kriisiin perustuva syynsä.

Hoitamisen eettisyyttä pidetään usein niin itsestään selvästi hoitamiseen kuuluvana olemuksena, että sen yksityiskohtainen tutkiminen on tarpeellista. Eettisyys haastaa tarkastelemaan ihmisyyteen kuuluvia perustavanlaatuisia kysymyksiä, jotka lähtevät alustavasti itseymmärryksestä ja omaksutusta maailmankuvasta. Millainen olen ja miten suhtaudun muihin ihmisiin sekä mitä pidän elämässäni tärkeänä ja merkityksellisenä? Hoitamisen konteksti tuo eteen haastavia kysymyksiä: millainen hoitaminen johtaa asiakkaan tai potilaan hyvään ja hänen kannalta oikeisiin ratkaisuihin? Huomion kohteeksi tulevat hoitamisen maailmankuva ja sen perusteet. Mitä hoitamisessa pidetään merkityksellisenä sekä mikä on hoitajan asema ja tehtävä hyvän mahdollistajana? Ohjaavatko hoitajan toimintaa ulkopuoliset tekijät vai perustuuko se autonomiaan, tahtoon hoitamiseen asettautumisesta?

Tieto, tiedostaminen ja ymmärtäminen ovat myös oleellisesti esillä pohdittaessa ammatillisen hoitamisen perusedellytyksiä. Tieto sinänsä on hyödytön, mikäli sitä ei ole saatavilla. Reaalisen maailman ominaisuuksiin kuuluu objektiivinen tieto, jota hyödynnetään hoitamisessa. Oleellista on se, millainen tieto nostetaan merkitykselliseen asemaan. Se vaikuttaa hoitajan havaitsemiseen, ymmärtämiseen, valintoihin ja toimintaan, sekä siihen, mitä ammattikunta pitää työssään tärkeänä, keskeisenä ja kehittämisen arvoisena.

Hoitajalla on mahdollisuus tavoittaa ihmisen inhimilliseen olemukseen perustuvaa sekä moraalista että eettistä tietoa tunnistamalla oman ihmisyytensä. Olemalla läsnä, kuuntelemalla toisten ja jäsentämällä omia kokemuksia, osallistumalla, eläytymällä, koskettamalla, tarkkailemalla, keskustelemalla ja ohjaamalla hän luo pohjaa tiedostamiselle ja ymmärtämiselle. Monipuolisessa vuorovaikutuksessa tunteillakin on sijansa. Tiedostaminen ja ymmärtäminen ovat eettisyyden 
ja moraalisuuden edellytyksiä. Oman toiminnan pohtiminen lisää itseymmärrystä. Moraalin tunne rakentuu henkilökohtaiseen moraalitietoon.

Ammatillisen hoitamisen olemuksen ja perusteiden ymmärtäminen auttaa hahmottamaan, mikä on sen oleellisin tehtävä: hoitaminen. Hoitaminen on eettistä ja praktista, jonka olemassaololle voidaan löytää perusteluja ihmisen eksistentiaalisen kriisin ja tiedon merkityksen parista.

\section{Lähteet}

Airaksinen, T. (1988). Moraalifilosofia. Helsinki: WSOY.

Airaksinen, T. (2002). Ammattien ja ansaitsemisen etiikka. Näkemyksiä ammattien, johtamisen ja liike-elämän arvoista. 3. painos. Helsinki: Yliopistopaino.

Austin, W. (2001). Using the human rights paradigm in health ethics: the problems and possibilities. Nursing Ethics 8(3), 183-195.

Bandman, E.L. \& Bandman, B. (1995). Nursing ethics through the life span. 3. painos. Connecticut: Appleton \& Lange.

Benjamin, M. \& Curtis, J. (1992). Ethics in nursing. New York: Oxford University Press.

Blondeau, D. (2002). Nursing art as a practical art: the necessary relationship between nursing art and nursing ethics. Nursing Philosophy, 3(3), 252-259.

Botes, A (2000). A comparison between the ethics of justice and the ethics of care. Journal of Advances Nursing, 32(5), 1071-1075.

Carper, B.A. (1978). Fundamental Patterns of Knowing in Nursing. Journal of Advances Nursing, 1(1), 13-23.

Cortis, J. \& Kendrick, K. (2003). Nursing ethics, caring and culture. Nursing Ethics, 10(1), 7788.

Easter, A. (2000). Construct analysis of four modes of being present. Journal of Holistic Nursing, 18(4), 362-377.

Eriksson, E. (1987). Hoitamisen idea. Sairaanhoitajien koulutussäätiö. Alkuperäisteoksen Vårdandets idé vuodelta 1987 suomentanut Birgitta Sumelius.

Eriksson, K. (1989). Caritas-idea. Alkuperäisteoksen Pausen - En beskriving av vårdvetenskapens kunskapsobjekt vuodelta 1987 suo- mentanut Birgitta Sumelius. Helsinki: Sairaanhoitajien koulutussäätiö.

Eriksson, K. (1990). Pro Caritate. En lägesbestämning av caritativ vård. Vårdforskning 2/ 1990. Institutionen för vårdvetenskap, Vasa: Åbo Akademi.

Eriksson, K. (1995). Mot en caritativ vårdetik. Vårdforskning. Institutionen för vårdvetenskap. Reports from the Development of Caring Science 5/1995. Vasa: Åbo Akademi.

Eriksson, K. (1996). Kärsivä ihminen. Åbo Akademi. Samhälls- och vårdvetenskapliga fakulteten, Institutionen för vårdvetenskap. Vasa: Åbo Akademi.

Eriksson, K. (2003). Ethos. Teoksessa Katie Eriksson ja Unni Å Lindström (ed.) Gryning II. Klinisk vårdvetenskap. Vasa: Åbo Akademi.

Fitzgerald, L. \& Hooft, S. (2000). A Socratic dialogue on the question "What is love in nursing”?, Nursing Ethics, 7(6), 481-491.

Flaming, D. (2004). Nursing theories as nursing ontologies. Nursing Philosophy, 5(3), 224229.

Grönroos, J., Lindholm, L., Lindström, U.Å., (1994). Karitatiivinen hoitoteoria. Teoksessa Hoitotyön teoreetikot ja heidän työnsä. Raija Viitasen käännös teoksesta Nursing Theoristis and Their Work vuodelta 1994. Helsinki: Sairaanhoitajien koulutussäätiö.

Haho, A. (2006). Hoitamisen olemus. Hoitotyön historiasta, teoriasta ja tulkinnasta hoitamista kuvaaviin teoreettisiin väittämiin. Väitöskirja. Oulu: Oulu University press.

Haho, A. (2007a). Lectio praecursoria. Hoitamisen olemus - Hoitotyön historiasta, teoriasta ja tulkinnasta hoitamista kuvaaviin teoreettisiin väittämiin. Premissi 2 (2), 46-48.

Haho, A. (2007b). Hoitamisen eettisyys sen olemuksen näkökulmasta. Pro Terveys 35 (4), 4-5.

Hansen, I. (2004). An intercultural nursing perspective on autonomy. Nursing Ethics, 11(1), 28-41.

Heidegger, M. (2000). Oleminen ja aika. Alkuteos Sein und Zeit ilmestyi vuonna 1927. Suomentanut Reijo Kupiainen. Tampere: Osuuskunta Vastapaino.

Heikkinen, E. (2003). Malli terveysalan käytännössä ja koulutuksessa ilmenevästä kateudesta. Väitöskirja. Oulun yliopisto. 
Hunt, G. (2004). A sense of life: the future of industrial-style health care. Nursing Ethics 11(2), 189-202.

Hämäläinen, J. \& Niemelä, P. (1993) Sosiaalialan etiikka. Helsinki: WSOY.

Häyry, M. (2001). Mahdollisimman monen onnellisuus. Utilitarismin historia, teoria ja sovellukset.

Kalkas, H. \& Sarvimäki, A. (2002). Hoitotyön etiikan perusteet. 5 . uudistettu painos. Helsinki:WSOY.

Kokko, S. (2004). Mielenterveystoimiston asiakkaiden ja työntekijöiden käsityksiä hyvästä mielenterveystyöstä. Arvoteoreettinen näkökulma mielenterveystyöhön. Väitöskirja. Oulu: Oulu University Press.

Kupiainen, R. (2005). Heideggerin faktisuuden hermeneutiikka. Teoksessa Tulkinnasta toiseen, Esseitä hermeneutiikasta. Toimittanut Jarkko Tontti. Tampere: Osuuskunta Vastapaino.

Kusch, M. (1986) Ymmärtämisen haaste. Yleisen aate- ja oppihistorian lisensiaatintutkimus, Oulun yliopisto.

Lauri, S. \& Elomaa, L. (1999). Hoitotieteen perusteet. 3. uudistettu painos. Helsinki: WSOY.

Leino-Kilpi, H. \& Välimäki, M. (2004). Etiikka hoitotyössä. Helsinki: WSOY.

MacIntyre, A. (2004). Hyveiden jäljillä. Moraaliteoreettinen tutkimus. Alkuteos After Virtue: A Study in Moral Theory ilmestyi vuonna 1981. Suomentanut Niko Noponen. Helsinki: Gaudeamus.

Mackintosh, C. (2000). Is there a place for "care” within nursing? International Journal of Nursing Studies, 37(2000), 321-327.

Marriner-Tomey, A. (1994). Hoitotyön teoreetikot ja heidän työnsä. Raija Viitasen käännös teoksesta Nursing Theoristis and Their Work vuodelta 1994. Helsinki: Sairaanhoitajien koulutussäätiö.

Matilainen, D. (1997) Idémönster i Karin Neuman-Rahns livsgärning och författarskap. En Idehistorisk-biografisk studie i psykiatrisk vård i Finland under 1900-talets första hälft. Väitöskirja. Vasa: Åbo akademis förlag Åbo akademi university press.

Matilainen, D. (2002) .Det själsliga lidandet och idémönster i vårdandets ethos. Teoksessa
Katie Eriksson ja Dahly Matilainen (toim.) Vårdandets och vetenskapens idéhistoria. Strövtåg i spårandet av "caritas originalis". Åbo Akademi. Vårdförskning 8/2002. Institutionen för vårdvetenskap.

Myllylä, M. (2004). Diakonisen hoitotyön mallin rakentaminen. Väitöskirja. Oulun yliopisto.

Nelson, S. (2004). The search for the good in nursing? The burden of ethical expertice. Nursing Philosophy, 5(1), 12-22.

Nores, T. (1993). Olemassaolokokemus. Naisvanhuspotilaan olemassaolokokemusta koskeva käsitteellinen ja empiirinen analyysi. SHKS:n julkaisu väitöskirjasta. Hoitotieteenlaitos, Turun yliopisto.

Nurminen, R. (2000). Intuitio ja hiljainen tieto hoitotyössä. Väitöskirja. Kuopio: Kuopion yliopiston painatuskeskus.

Nussbaum, M. C. (2000). Women and human development. The capabilities approach. Cambridge University Press.

Nussbaum, M. C. (2001). Upheavals of Though. The Intelligence of Emotions. Cambridge University Press.

Nussbaum, M. C. (2002). Therapeutic Arguments and Structures of Desire. Teoksessa Genevieve Lloyd (Ed.). Feminism and History of Philosophy. New York: Oxford University Press.

Paldanius, A. (2002). Lähimmäisenrakkaus hoitotyön koulutuksessa. Miten hoitotyön opiskelijat kuvaavat lähimmäisenrakkautta koulutuksen ja työkokemuksen edetessä? Väitöskirja. Rovaniemi: Lapin Yliopistopaino.

Parviainen, J. (2000). Kehollinen tieto ja ajatus. Ajatus 57, Copyright by Suomen Filosofinen yhdistys, 147-166.

Peacoc, J.W. \& Nolan, P.W (2000). Care under threat in the modern world. Journal of Advanced Nursing 32(5), 1066-1070.

Pietarinen, J. \& Poutanen, S. (2003). Etiikan teorioita. Helsinki: Gaudeamus.

Purola, H. (2000). Kotona asuvan aivoverenkiertohäiriöpotilaan ja hänen omaisensa kokemuksia selviytymisestä. Väitöskirja. Oulu: Oulu University Press.

Reynold, W.S. (2000). Nursing, empathy and perception of the moral. Journal of Advanced Nursing, 32(1), 235-242. 
Rosqvist, E. (2003). Potilaiden kokemukset henkilökohtaisesta tilastaan ja sen säilymisestä sisätautien vuodeosastoilla. Väitöskirja. Oulu: Oulu University Press.

Sarvimäki, A. (1988). Nursing care as a moral, practical, communicative and creative activity. Journal of Advanced Nursing 13(4), 463-467.

Tarlier, D.S. (2004). Beyond caring: the moral and ethical bases of responsive nurse-patient relationships. Nursing Philosophy 5(3), 229241.

Tuomi, J. (1997). Suomalainen hoitotiedekeskustelu. Väitöskirja. Jyväskylän yliopisto.

Tuulio. T. (1937). Florence Nightingale. Nykyaikaisen sairaanhoidon luoja. Helsinki: WSOY.

Vuokila-Oikkonen, P. (2002). Akuutin psykiatrisen osastohoidon yhteistyöneuvottelun keskustelussa rakentuvat kertomukset. Väitöskirja. Oulu: Oulu University Press.

Voipio, E. (1936). Sairaanhoitajattarien oppikirja. Sairaanhoidon alkeet. Sairaanhoitajatarjärjestöjen oppikirjakomitean julkaisema III Sairaanhoidon alkeet, Sairaanhoidon alkeiden käsikirja (jälkimmäisen osan on kirjoittanut Irja Pohjala). Helsinki: WSOY.

Watson, J. (1979). Nursing: The philosophy and science of caring. Colorado associated university press. Little Brown and Company.

Watson, J. (1988). Nursing: Human science and human care. A theory on nursing. National New York: League for Nursing.

Whelton, B. J. B. (2002). The multifaceted structure of nursing: an Aristotelian analysis. Nursing Philosophy 3(3), 193-204.

Åstedt-Kurki, P. (1992). Terveys, hyvä vointi ja hoitotyö kuntalaisten ja sairaanhoitajien kokemana. Väitöskirja. Tampere: Tampereen yliopisto.

Zizelsberger, H.M. (2004). Concerning technology: thinking with Heidegger. Nursing Philosphy, 5(3), 242-250.

\section{Viitteet}

1. Florence Nightingalen katsotaan käynnistäneen hoitotyön modernin aikakauden 1800-luvun puolessavälissä. Häntä pidetään myös ensimmäisenä hoitotyön teoreetikkona. (Tuulio 1937; MarrinerTomey 1994, 59.)
2. Jotta ymmärtäisimme hoitamisen ilmiötä, tarvitsemme sen ontologista kysymistä eli sen olemuksen alkuperän selvittämistä. Penttisen $(2003,16)$ mukaan filosofisen tutkimuksen tehtävä on selvittää ilmiön ontologisia perusmäärityksiä ja tarjota ne erityistieteen käytettäväksi.

3. Esiymmärrys tarkoittaa sitä, että tarkasteltava ilmiö on jo ymmärretty jo tietyllä tavalla, ilman tarkempaa määrittelemistä (Penttinen 2003, 18).

4. Esimerkiksi Hämäläinen \& Niemelä (1993) määrittelevät profession ammatiksi, joka perustuu korkeakoulutasoiseen koulutukseen, jolla on oma eettinen säännöstö ja ammattijärjestö. Sille on luonteenomaista kokopäivätyö ja se on julkisesti tunnustettu eli toimimiseen on julkiset lisenssit. Katso myös Airaksinen 2002, 25.

5. Peacoc \& Nolanin (2000) näkemyksen mukaan tieteellisen tiedon painottaminen on tyypillistä positivistisissa tieteissä.

6. Austinin (2001) mukaan ihmisoikeudet ajavat sosiaalista hyvää ja ihmisten terveyttä. Ne eivät kuulu ihmisen yksilölliseen olemukseen. Tulkitsen tämän siten, että oikeudenmukaisuuden toteutuminen on järjestelmän ominaisuus, ei yksittäisen ihmisen. Hänen ominaisuuteen kuuluu inhimillisyys.

7. Eriksson (1987), Mackintosh (2001) ja Blondeau (2002) ovat esittäneet aikaisemmin saman näkemyksen.

8. Kävin tarkemmin läpi 27 tieteellistä artikkelia ja tutkimusta, joissa määriteltiin tai kuvattiin hoitotyötä ja hoitamista. Niissä kuvattiin jokin hoitotapahtuma tai niissä pohdittiin jotakin hoitamiseen kuuluvaa ilmiötä, kuten rakkautta, intuitiota tai empatiaa. Valitsin artikkelit harkitun otannan perusteella, jotka vastasivat tutkimuskysymykseen. Näitä olivat esimerkiksi Watson 1979, 1988; Botes 2000; Fitzgerald \& Van Hooft 2000; Nurminen 2000; Peacock \& Nolan 2000; Austin 2001; Mackintosh 2001; Blondeau 2002; Cortis \& Kendrick 2003; Flaming 2004; Hunt 2004; Nelson 2004; Zizelsberger 2004.

9. Lukija voi perehtyä länsimaisen subjektikokemuksen tutkimuksen pioneerin, teologi ja filosofi Augustinuksen (345-430) omanelämänkertaan 
Tunnustukset. Hän pohtii siinä tiedon alkuperää ja sen saavuttamisen mahdollisuutta oman kasvuja kehitysprosessin kautta. Tunnustukset kuvaavat minuuden ja identiteetin rakentumista, niihin vaikuttavia tekijöitä sekä itsetuntemisen saavuttamista.

10. ’Täälläolo ymmärtää itsensä suhteessa olemiskykyynsä siten, että kohtaa kuoleman silmästä silmään omaksuakseen näin heitteisyydessään kokonaan olevan, jota se itse on.” Heidegger 2000, 73, 455 .

11. Nussbaumin (2000, 249-50) käsityksen mukaan liberalistinen traditio, jossa oikeudenmukaisuuden, tasavertaisuuden ja tasa-arvon edistäminen ovat olleet ensisijalla, on vaikuttanut sen syrjäytyneeseen asemaan.

12. Jo tämä toteamus kaatuu naturalistiseen virhepäätelmään. Mutta jostakin on lähdettävä ja joitakin totuuksia on hyväksyttävä. Muussa tapauksessa edessä on skeptismiin ja nihilismiin vajoaminen, mikä taas on vastuutonta tieteen harjoittamista. Moraalifilosofisten perusteiden kysymisestä tarkemmin Haho 2006, 118-132.

13. Jonka mukaan moraaliväitteillä ei ole totuusluonnetta, koska sijoittuvat maailman tosiasioiden ulkopuolelle.

14. Tiedollinen kokemus todetaan suoraan ja vä- littömästi, intuitiivisesti, ”itsestään selvästi”. Intuitiivinen tieto on muotoutunut harkinnan tuloksena, se ilmaistaan selkeästi ja täsmällisesti, sen tulee läpäistä kriittisen itsetietoisuuden sekä olla sopusoinnussa kaikkien muiden pätevien intuitioiden kanssa. Airaksinen 1988, 30; Häyry 2001, 117; Pietarinen \& Poutanen 2003.

15. Suosittelen luettavaksi Martin Kuschin teoksen Ymmärtämisen haaste (1986), joka perustuu hänen lisensiaattityöhönsä.

16. Löydän tässä yhteyden eettisen tiedon praktiseen luonteeseen, jota käsittelen seuraavaksi.

Artikkeli saapui toimitukseen 13.9.2007. Se hyväksyttiin julkaistavaksi toimituskunnan kokouksessa 24.8.2007. 